\title{
Microcytosis in children and adolescents with the sickle cell trait in Basra, Iraq
}

\author{
Rawshan Zuhair Jaber ${ }^{1}$, Meàad Kadhum Hassan ${ }^{1,2}$, Sadeq Khalaf Al-Salait ${ }^{1}$ \\ ${ }^{1}$ Center for Hereditary Blood Diseases, Basrah Heath Directorate, ${ }^{2}$ Department of Pediatrics, College of Medicine, University of \\ Basrah, Basrah, Iraq
}

p-ISSN 2287-979X / e-ISSN 2288-0011 https://doi.org/10.5045/br.2019.54.1.38 Blood Res 2019;54:38-44.

Received on April 13, 2018

Revised on August 29, 2018

Accepted on October 1, 2018

\section{Correspondence to}

Meàad Kadhum Hassan, M.D.

Department of Pediatrics, Basrah Medical

College, Al-Ashar-Corniche St, Al

Bradheia, Al Basra, Iraq

E-mail: alasfoor_mk@yahoo.com

(C) 2019 Korean Society of Hematology

\section{Background}

Microcytic anemia, the most common form of anemia in children and adolescents, is a heterogeneous group of diseases that is acquired or inherited. We assessed the frequency and causes of microcytosis in children and adolescents with the sickle cell trait (SCT).

\section{Methods}

This descriptive study included 95 subjects ( 49 males and 46 females) with SCT who attended Basra Center for Hereditary Blood Diseases for evaluation. Investigations included complete blood count, high performance liquid chromatography, capillary electrophoresis, and measurement of serum ferritin and transferrin levels.

Results

SCT subjects had a low hemoglobin $(\mathrm{Hb})$ concentration $(9.79 \pm 1.75 \mathrm{~g} / \mathrm{dL})$, low mean corpuscular volume (MCV, 67.43 \pm 9.22$)$, low mean corpuscular $\mathrm{Hb}(21.15 \pm 3.64)$, and a normal red cell distribution width (RDW, 14.00 \pm 2.30$)$. Among 95 SCT subjects, 81 $(85.26 \%)$ had microcytosis, $12(12.63 \%)$ had normal MCV, and 2 (2.11\%) exhibited macrocytosis. Sixty-three (77.78\%) SCT subjects with microcytosis were iron deficient, and $18(22.22 \%)$ had normal iron levels. The mean serum ferritin and $\mathrm{HbA} 2$ levels were significantly lower, while the RDW, sickle $\mathrm{Hb}$, and serum transferrin levels were significantly higher in patients with microcytosis and iron deficiency compared to non-iron deficient subjects $(P<0.05)$. Correlation coefficients did not reveal a significant association between the MCV and iron status of SCT subjects $(P>0.05)$.

\section{Conclusion}

Despite the frequent occurrence of iron deficiency in SCT subjects, co-inheritance of alpha-thalassemia seemed to be the cause of low MCV in non-iron deficient individuals with microcytosis. Genetic analysis is required to understand the genetic basis of this phenomenon.

Key Words Microcytosis, Sickle cell trait, Children

\section{INTRODUCTION}

The sickle cell trait (SCT) has been detected in approximately 300 million individuals worldwide. It has long been considered a benign carrier state providing relative protection against severe malaria [1]. However, clinical sequelae, such as exercise-related injury, renal complications, and venous thromboembolism, can occur in affected carriers [2]. Overall, evidence suggests that SCT may be neither a completely benign carrier state nor a true disease entity, but rather a risk factor for certain adverse outcomes that result from the interaction between genetic and environmental influences [3]. In the Basra governorate of southern Iraq, $6.48 \%$ of the population are carriers of the sickle hemoglobin $(\mathrm{HbS})$ gene, giving a gene frequency of 0.0324 [4]. Another study in Dohuk in northern Iraq reported 1.2\% carriers within the population of the concerned governorate [5].

Microcytic anemia is the most common form of anemia in children and adolescents. It represents a very heterogeneous group of diseases that may be either acquired (mostly due to iron deficiency) or inherited. Microcytic hypochromic 
anemia can result from a defect in globin genes (hemoglobinopathies or thalassemias), heme synthesis, or iron availability or acquisition by erythroid precursors [6]. Iron deficiency (ID) is the most common cause of anemia worldwide. However, iron deficiency anemia (IDA) is not distributed evenly across the world, exhibiting is a five-fold higher incidence in underdeveloped countries [7]. In 2011, the Southeast Asian, Eastern Mediterranean, and African regions of the WHO exhibited the lowest mean blood hemoglobin concentrations and the highest prevalence of anemia across population groups [8]. In Iraq, the prevalence of iron deficiency (ID) in children younger than five years of age is $14.4 \%$, and the prevalence of IDA is $6.8 \%$ [9].

While the co-inheritance of another $\beta$-globin gene increases the proportion of $\mathrm{HbS}$ and therefore the risk of sickling, the combination with a deletion of an $\alpha$-gene reduces intraerythrocytic $\mathrm{HbS}$ concentration, which consequently attenuates the problems due to SCT [10]. The co-inheritance of $\alpha^{+}$-thalassemia could reduce the effects of $\mathrm{HbS}$ on erythrocyte pathophysiology. The AS hemoglobin genotype likewise ameliorates both the reduced mean corpuscular volume (MCV) and mean corpuscular hemoglobin $(\mathrm{MCH})$ values normally associated with the $-\alpha /-\alpha$ genotype [11]

The present study was conducted to investigate the causes of microcytosis among children and adolescents with SCT in Basra and to evaluate selected hematological and biochemical variables in subjects with SCT and microcytosis.

\section{MATERIALS AND METHODS}

Children and adolescents referred to the Center for Hereditary Blood Diseases (CHBD) at the Basra Maternity and Children's Hospital for suspected hemoglobinopathy were enrolled in this descriptive study lasting from 1st October 2015 through February 2016. A total of 95 symptomatic and asymptomatic children and adolescents, with ages ranging from 6 months to 18 years, were included in the study.

\section{Data collection}

Information obtained from the subjects included specification of gender, date of birth, residence, reason for referral to the CHBD for evaluation, drug history, use of supplements such as folic acid and iron, unusual dietary habits such as pica, history of hospitalization, history of blood transfusion, and family history of anemia. Complete clinical data were collected including pallor, pain, renal symptoms, respiratory symptoms, jaundice, fever, and other manifestations of infection. For the patients referred preoperatively, the reason and type of operation were documented. A complete examination was performed on all subjects, which included general and systemic checkups. Informed consent was obtained from subjects and one of the parents before recruitment into the study. The study was approved by the Ethical Committee of Basra Medical College.

\section{Anthropometry}

The height and weight of all subjects in the study were measured using a stadiometer and electronic body scale, respectively. Subjects were weighed in light clothing, and height was measured to the nearest $0.1 \mathrm{~cm}$ with the subjects barefooted. The body mass index (BMI) was calculated based on the following formula: BMI=weight in kilograms/(height in meters) $)^{2}$. The z-scores for body mass index for age (BMIZ) were calculated for all subjects using the WHO 2006/2007 reference values. The WHO Anthro software version 3.2.2 was used for the global application of the WHO child growth standards for those younger than 5 years of age, and the WHO AnthroPlus software version 1.0.4 was used for the global application of the 2007 WHO reference values for the subjects at 5-19 years of age. Accordingly, subjects were classified as severely thin $(<-3 \mathrm{SD})$, thin $(<-2 \mathrm{SD})$, normal, overweight $(>+2 \mathrm{SD})$ or obese $(>+3 \mathrm{SD})[12,13]$.

\section{Laboratory data}

A complete blood count was performed, which included specification of the following parameters: $\mathrm{Hb}$ concentration, red blood cell (RBC) count, MCV, MCH, mean corpuscular hemoglobin concentration (MCHC), RBC distribution width-coefficient of variation (RDW-CV), white blood cell (WBC) count, and platelet count. The CELL-DYN Ruby System from Abbott Diagnostics was regularly calibrated to obtain accurate results of the blood analysis. Daily quality control was performed by the hematologist at the CHBD. Reference values, according to age, of the most important blood count parameters were extracted from Refs. [14, 15].

High-performance liquid chromatography (HPLC) and the ADAMS HA-8180T analyzer (ARKRAY, Inc., Kyoto, Japan) were used for the quantification of fetal hemoglobin $(\mathrm{HbF})$, $\mathrm{HbA2}$, and the detection of variant hemoglobin.

Hemoglobin capillary electrophoresis (CE) was used for a more substantial confirmation of hemoglobin $\mathrm{S}$ detected by HPLC and for detecting the presence of $\mathrm{HbH} / \mathrm{Bart}$ 's disease. The system was also useful for the detection and quantification of other hemoglobin variants. Quantitative analysis of $\mathrm{Hb}$ Bart's was performed by a high voltage and resolution $\mathrm{Hb}$ separation technique using the capillary electrophoresis system (Sebia Capillarys 2, Sebia Inc., Georgia, USA). Hb Bart's fractions were identified in zone 12. An $\mathrm{HbH}$ preparation was concocted using New Methylene Blue stain (as a supravital stain) at two volumes of stain to one volume of blood. The mixture was incubated for 2 hours, then smeared on a slide to be examined by a hematologist for any $\mathrm{HbH}$ inclusions in the RBCs.

Sera from children and adolescents with SCT were obtained by centrifugation of the collected blood samples in vacuum gel tubes. The serum was used for the assessment of iron status according on the following assays:

The serum ferritin level was assessed using the FERR Gen.4 Cobas C kit from Roche Diagnostics (Cat. No. 4885317190), and serum transferrin was assessed using the TRSF Gen.2 Cobas C kit from Roche Diagnostics (Cat. No. 3015050122). Both tests were performed on a Cobas Integra 
400 (Roche Diagnostics Ltd., Switzerland).

The transferrin/log (ferritin) ratio was used to differentiate between IDA and non-IDA subjects at a transferrin/log (ferritin) ratio cut-off value of $1.70(\leq 1.70$ :non-iron-deficient; >1.70:ID) [16].

\section{Statistical analysis}

All statistical analyses were performed using the Statistical Package for the Social Sciences version 20.0 (IBM SPSS Corp., Armonk, NY, USA). Comparisons of proportions were per-

Table 1. Selected demographic and clinical characteristics of children and adolescents with sickle cell trait.

\begin{tabular}{lc}
\multicolumn{1}{c}{ Variable } & Total $(\mathrm{N}=95, \%)$ \\
\hline Age $(\mathrm{yr})$ & \\
$<1$ & $11(11.58)$ \\
$1-5$ & $41(43.16)$ \\
$>5-10$ & $25(26.31)$ \\
$>10-15$ & $16(16.84)$ \\
$>15$ & $2(2.11)$ \\
Gender & \\
Male & $49(51.58)$ \\
Female & $46(48.42)$ \\
Residence & \\
Center & $66(69.47)$ \\
Periphery & $29(30.53)$ \\
Reasons for referral & \\
Pallor & $42(44.21)$ \\
Bone pain & $21(22.11)$ \\
Infections & $11(11.58)$ \\
Stroke & $1(1.02)$ \\
Screening & $20(21.05)$ \\
Previous hospitalization & \\
Yes & $56(58.95)$ \\
No & $39(41.05)$ \\
Previous blood transfusion & \\
Yes & $7(7.37)$ \\
No & $88(92.63)$ \\
Drug history & \\
Folic acid & $37(38.95)$ \\
Iron therapy & $7(7.37)$ \\
Folic acid and iron & $3(3.16)$ \\
No drug & $48(50.52)$ \\
\hline$\quad$ &
\end{tabular}

formed by crosstab using the chi-square test in the case when each cell had an expected frequency of five or more, and Fisher's exact test was applied when one or more of the cells had an expected frequency of less than five in a table. Intra-class differences in the parameters between two average values of different samples were analyzed using the independent t-test. Inter-class differences of MCV values and selected hematological and biochemical parameters were determined using one-way analysis of variance (ANOVA), and several post-hoc comparisons of the averages were performed using Scheffé test. Correlation coefficient analysis (Spearman's rho correlation test) was used to assess the association between iron status and MCV levels in SCT subjects. Statistical tests with probability values $P<0.05$ were considered statistically significant.

\section{RESULTS}

The total number of children and adolescents enrolled in this study was 95, and their ages ranged from 6 months to 18 years with a mean age of $6.04 \pm 4.46$ years. Fifty-two $(54.74 \%)$ of the children and adolescents in this study were $\leq 5$ years of age, and the male to female ratio was 1.06 . Most of these subjects lived in the Basra Center (69.47\%), as illustrated in Table 1 . Seventy-five $(78.95 \%)$ of the studied subjects were symptomatic and referred to the CHBD for evaluation, and only $20(21.05 \%)$ were asymptomatic and referred because of a positive family history of sickle cell disease. Pallor was the main symptom (44.21\%), followed by bone pain (22.11\%). Other causes of referral were bronchopneumonia $(9.47 \%)$ and urinary tract infection $(2.11 \%)$, as well as one case of left-sided weakness and repeated seizures.

A history of previous hospitalization was reported in 39 (41.05\%) of the studied subjects, with infections occurring in $21(22.10 \%)$ subjects, followed by $9(9.47 \%)$ subjects being hospitalized for anemia. A total of 7 (7.37\%) subjects had a previous history of blood transfusions (3 due to severe IDA, and 4 due to glucose-6-phosphate dehydrogenase

Table 2. Hematological parameters of symptomatic and asymptomatic subjects with sickle cell trait.

\begin{tabular}{lcccc}
\hline \multicolumn{1}{c}{ Variable } & $\begin{array}{c}\text { Symptomatic }(\mathrm{N}=75), \\
\text { Mean } \pm \mathrm{SD}\end{array}$ & $\begin{array}{c}\text { Asymptomatic }(\mathrm{N}=20), \\
\text { Mean } \pm \mathrm{SD}\end{array}$ & $\begin{array}{c}\text { Total }(\mathrm{N}=95), \\
\text { Mean } \pm \mathrm{SD}\end{array}$ & $P$ \\
\hline $\mathrm{Hb}(\mathrm{g} / \mathrm{dL})$ & $9.70 \pm 1.89$ & $10.13 \pm 1.04$ & $9.79 \pm 1.75$ & 0.342 \\
$\mathrm{WBC}\left(\times 10^{9} / \mathrm{L}\right)$ & $7.23 \pm 2.88$ & $8.62 \pm 2.47$ & $7.53 \pm 2.84$ & 0.054 \\
$\mathrm{RBC}$ count $\left(\times 10^{12} / \mathrm{L}\right)$ & $4.70 \pm 0.96$ & $4.72 \pm 0.60$ & $4.71 \pm 0.90$ & 0.957 \\
$\mathrm{MCV}(\mathrm{fL})$ & $67.37 \pm 9.69$ & $67.64 \pm 7.42$ & $67.43 \pm 9.22$ & 0.908 \\
$\mathrm{MCH}(\mathrm{pg})$ & $20.98 \pm 3.70$ & $21.79 \pm 3.42$ & $21.15 \pm 3.64$ & 0.383 \\
$\mathrm{MCHC}(\mathrm{g} / \mathrm{dL})$ & $31.15 \pm 2.81$ & $32.13 \pm 3.03$ & $31.35 \pm 2.87$ & 0.178 \\
$\mathrm{RDW}-\mathrm{CV}(\%)$ & $14.00 \pm 2.35$ & $14.00 \pm 2.17$ & $14.00 \pm 2.30$ & 0.998 \\
Platelets $\left(\times 10^{9} / \mathrm{L}\right)$ & $333.05 \pm 131.96$ & $372.40 \pm 114.11$ & $341.33 \pm 128.84$ & 0.227 \\
\hline
\end{tabular}

Abbreviations: $\mathrm{Hb}$, hemoglobin; $\mathrm{MCH}$, mean corpuscular hemoglobin; $\mathrm{MCHC}$, mean corpuscular hemoglobin concentration; $\mathrm{MCV}$, mean corpuscular volume; RBC, red blood cell; RDW, red cell distribution width; WBC, white blood cells. 
(G6PD) deficiency). Four patients had surgery including tonsillectomy (two cases) and orthopedic causes (one case due to fracture, and the other due to avascular necrosis of the hip), as displayed in Table 1 . The $\mathrm{Hb}$ concentrations in studied subjects ranged from $5.71 \mathrm{~g} / \mathrm{dL}$ to $16.60 \mathrm{~g} / \mathrm{dL}$, and the MCV ranged from $45 \mathrm{fL}$ to $94 \mathrm{fL}$, with $81(85.26 \%)$ of the SCT subjects exhibiting low $\mathrm{Hb}$ concentrations compared to the values of healthy subjects of the same age and gender. Although the average values of $\mathrm{Hb}, \mathrm{MCV}, \mathrm{MCH}$, and $\mathrm{MCHC}$ for all SCT subjects were lower than those of healthy individuals, no statistically significant difference in these variables was reported between symptomatic and asymptomatic subjects. This case was similar for other variables (RBC count, RDW-CV, WBC count, and platelet count); $P>0.05$. Among the 75 symptomatic SCT subjects, 64 (85.33\%) had low MCV compared to $17(85 \%)$ subjects with low MCV in the asymptomatic group, $P>0.05$ (Table 2).

Low MCV was reported in 81 (85.26\%) subjects, while 12 (12.63\%) subjects had normal MCV, and only $2(2.05 \%)$ had high MCV. Out of the 49 male subjects with SCT, 47 (95.92\%) of them had low MCV, and only 2 (4.08) had normal MCV. Out of a total of 46 female subjects with SCT, $34(73.91 \%)$ of them had microcytosis, while 10 (21.74\%) had normal MCV, and 2 (4.35\%) had high MCV. The difference in MCV between the genders was statistically significant $(P=0.006)$. The study also revealed that the average values of $\mathrm{MCV}, \mathrm{MCH}$, and $\mathrm{S}$. ferritin were significantly lower in male subjects with SCT compared to female $(P<0.05)$, while other hematological variables did not exhibit a significant difference between the genders, as illustrated in Table 3.

Children and adolescents with SCT and microcytosis had a significantly lower mean $\mathrm{MCH}$ and $\mathrm{S}$. ferritin level $(20.44 \pm 3.36 \mathrm{pg}$ and $42.33 \pm 6.75 \mathrm{ng} / \mathrm{mL}$, respectively) compared to those with normal MCV $(24.60 \pm 1.48 \mathrm{pg}$ and $73.28 \pm 23.59 \mathrm{ng} / \mathrm{mL}$, respectively) and subjects with high MCV $(29.30 \pm 1.69 \mathrm{pg}$ and $217.30 \pm 164.90 \mathrm{ng} / \mathrm{mL}$, respectively). The averages of the $\mathrm{RBC}$ count and $\mathrm{RDW}-\mathrm{CV}$ were significantly higher in the microcytic group $\left(4.83 \pm 0.85 \times 10^{12} / \mathrm{L}\right.$ and $14.25 \pm 2.38 \%$, respectively) compared to those in the normocytic group $\left(4.09 \pm 0.72 \times 10^{12} / \mathrm{L}\right.$ and $12.50 \pm 0.91 \%$, respectively) and the macrocytic group $\left(3.13 \pm 1.4110^{12} / \mathrm{L}\right.$ and $12.90 \pm 1.41 \%$, respectively); $P<0.05$. Multiple comparisons of the obtained averages using the Scheffé test showed that children and adolescents with microcytosis had a significantly higher RBC count $(P=0.021)$ and RDW-CV $(P=0.047)$ compared to those with normocytosis.

Out of the 81 subjects with microcytosis, 63 (77.78\%) of them had ID, while the remaining 18 (22.22\%) had normal iron status. Results of the capillary electrophoresis diagnosed one subject with Hb-Bart's disease and co-inheritance of $\alpha$-thalassemia. Among subjects with SCT and normal MCV, $8(66.67 \%)$ had ID, and $4(33.33 \%)$ were not iron deficient. The distribution of iron status did not reveal significant changes in the frequency of MCV among those with or without ID $(P>0.05)$, indicating that microcytosis was not

Table 4. Selected hematological and biochemical parameters in subjects with microcytosis relative to iron status.

\begin{tabular}{lrcc}
\hline \multirow{2}{*}{\multicolumn{1}{c}{ Variables }} & \multicolumn{2}{c}{ Microcytosis $(\mathrm{N}=81)$} & \\
\cline { 2 - 3 } & $\begin{array}{c}\text { ID }(\mathrm{N}=63), \\
\text { Mean } \pm \mathrm{SD}\end{array}$ & $\begin{array}{c}\text { Non-ID }(\mathrm{N}=18), \\
\text { Mean } \pm \mathrm{SD}\end{array}$ & \\
\hline $\mathrm{Hb}(\mathrm{g} / \mathrm{dL})$ & $9.72 \pm 1.89$ & $9.95 \pm 1.16$ & 0.622 \\
$\mathrm{RBCs}\left(\times 10^{12} / \mathrm{L}\right)$ & $4.83 \pm 0.88$ & $4.85 \pm 0.75$ & 0.915 \\
$\mathrm{MCH}(\mathrm{pg})$ & $20.32 \pm 3.33$ & $20.87 \pm 3.54$ & 0.541 \\
$\mathrm{MCHC}(\mathrm{g} / \mathrm{dL})$ & $31.19 \pm 2.95$ & $31.78 \pm 3.48$ & 0.471 \\
$\mathrm{RDW}-\mathrm{CV}(\%)$ & $14.65 \pm 2.46$ & $12.85 \pm 1.37$ & 0.004 \\
$\mathrm{~S}$. ferritin $(\mathrm{ng} / \mathrm{dL})^{\mathrm{a})}$ & $25.66 \pm 2.39$ & $100.66 \pm 25.23$ & 0.000 \\
$\mathrm{~S} . \operatorname{transferrin}(\mathrm{g} / \mathrm{L})$ & $3.31 \pm 0.47$ & $2.54 \pm 0.30$ & 0.000 \\
$\mathrm{HbA}(\%)$ & $2.75 \pm 0.45$ & $3.18 \pm 0.60$ & 0.002 \\
$\mathrm{HbS}(\%)$ & $33.38 \pm 4.89$ & $30.47 \pm 6.95$ & 0.047 \\
\hline
\end{tabular}

${ }^{a)}$ SE: standard error.

Abbreviations: $\mathrm{Hb}$, hemoglobin; ID, iron deficient; $\mathrm{MCH}$, mean corpuscular hemoglobin; MCHC, mean corpuscular hemoglobin concentration; RBCs, red blood cells; RDW, red cell distribution width; S., serum.

Table 3. Selected hematological and biochemical variables among sickle cell trait children and adolescents relative to gender.

\begin{tabular}{lcccc}
\multicolumn{1}{c}{ Variables } & $\begin{array}{c}\text { Male }(\mathrm{N}=49), \\
\text { Mean } \pm \mathrm{SD}\end{array}$ & $\begin{array}{c}\text { Female }(\mathrm{N}=46), \\
\text { Mean } \pm \mathrm{SD}\end{array}$ & $\begin{array}{c}\text { Total }(\mathrm{N}=95), \\
\text { Mean } \pm \mathrm{SD}\end{array}$ \\
\hline $\mathrm{Hb}(\mathrm{g} / \mathrm{dL})$ & $9.66 \pm 1.28$ & $9.93 \pm 2.16$ & $9.79 \pm 1.75$ & 0.469 \\
$\mathrm{RBC}$ count $\left(\times 10^{12} / \mathrm{L}\right)$ & $4.88 \pm 0.67$ & $4.52 \pm 1.07$ & $4.71 \pm 0.90$ & 0.056 \\
$\mathrm{MCV}(\mathrm{fL})$ & $64.36 \pm 8.14$ & $70.69 \pm 9.26$ & $67.43 \pm 9.22$ & 0.001 \\
$\mathrm{MCH}(\mathrm{pg})$ & $20.08 \pm 3.49$ & $22.30 \pm 3.48$ & $21.15 \pm 3.64$ & 0.003 \\
$\mathrm{MCHC}(\mathrm{g} / \mathrm{dL})$ & $31.21 \pm 2.91$ & $31.51 \pm 2.85$ & $31.35 \pm 2.87$ & 0.605 \\
$\mathrm{RDW}(\%)$ & $14.40 \pm 2.40$ & $13.58 \pm 2.13$ & $14.00 \pm 2.30$ & 0.081 \\
$\mathrm{Hb} \mathrm{S}(\%)$ & $30.31 \pm 5.64$ & $32.03 \pm 4.83$ & $31.15 \pm 5.30$ & 0.115 \\
S. ferritin $(\mathrm{ng} / \mathrm{dL})^{\mathrm{a})}$ & $35.06 \pm 4.22$ & $65.75 \pm 14.36$ & $49.92 \pm 7.41$ & 0.038 \\
S. transferrin $(\mathrm{g} / \mathrm{L})$ & $3.15 \pm 0.51$ & $3.11 \pm 0.53$ & $3.11 \pm 0.52$ & 0.706 \\
\hline
\end{tabular}

${ }^{\text {a) }} \mathrm{SE}$ : standard error.

Abbreviations: $\mathrm{Hb}$, hemoglobin; $\mathrm{MCH}$, mean corpuscular hemoglobin; $\mathrm{MCHC}$, mean corpuscular hemoglobin concentration; $\mathrm{MCV}$, mean corpuscular volume; RBC, red blood cell; RDW, red cell distribution width; S., serum. 
related to ID alone. Among the subjects with ID, 36 (57.14\%) were $<5$ years of age, $12(19.05 \%)$ had a history of pica, $3(4.76 \%)$ received blood, and $32(50.80 \%)$ were receiving iron, folic acid, or both. In addition, 14 (22.22\%) patients with SCT, microcytosis, and ID had low BMIZ (thin and severely thin). This study also revealed that in SCT individuals with microcytosis and ID, the average levels of $\mathrm{S}$. ferritin and $\mathrm{HbA2}$ were significantly lower, and the averages of RDW-CV, serum transferrin, and $\mathrm{HbS}$ were significantly higher in comparison to non-ID subjects; $P<0.05$, Table 4.

Correlation coefficients did not reveal a significant association between MCV and iron status in SCT subjects $(P>0.05)$, Fig. 1. However, among the subjects with microcytosis, a different correlation pattern was discovered between MCV and iron status in ID (Fig. 2A) compared to the non-ID group (Fig. 2B).

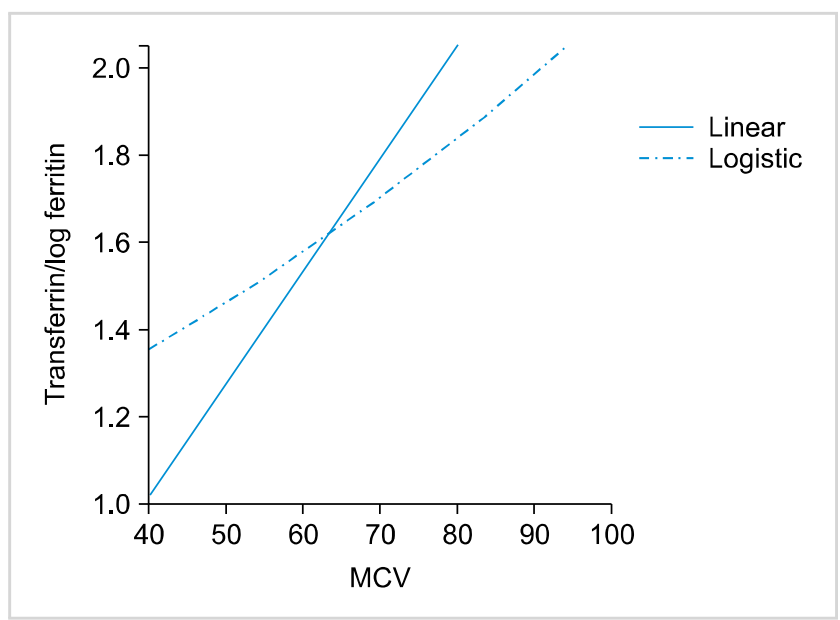

Fig. 1. Correlation between MCV level and iron status in SCT children and adolescents (Spearman's rho correlation test, $-0.063 ; P=0.546$ ).

\section{DISCUSSION}

This study assessed microcytosis in children and adolescents with SCT in Basra, southern Iraq, where the frequency of the disease is the highest in comparison with other Iraqi regions. The frequency of microcytosis was found to be high among SCT subjects, and although ID was reported in most of the cases, causes other than iron deficiency may have contributed to microcytosis in these subjects.

The mean $\mathrm{Hb}$ concentration in the study group was lower than that of healthy individuals, with no significant difference between symptomatic and asymptomatic SCT subjects and between male and female subjects. In the study of Obaid et al. in Basra, the mean $\mathrm{Hb}$ in healthy children with a comparable age $(5.90 \mathrm{yr})$ was $(11.50 \pm 0.99 \mathrm{~g} / \mathrm{dL})$ for male and $(11.39 \pm 1.20 \mathrm{~g} / \mathrm{dL})$ for female subjects [17].

In the study of Chikhlikar and Wilkinson [18] the mean $\mathrm{Hb}$ in symptomatic SCT patients $(7.71 \pm 2.11 \mathrm{~g} / \mathrm{dL})$ was significantly lower in comparison to that in asymptomatic subjects $(12.98 \pm 2.02 \mathrm{~g} / \mathrm{dL})$.

Mustafa et al. [19] in Sudan reported that the blood profile in SCT subjects was comparable to that of healthy individuals, with a mean $\mathrm{Hb}$ of $12.50 \pm 1.98$. The low $\mathrm{Hb}$ reported in this study can be explained by the increased demand for growth, repeated infections, and poor dietary habits of subjects.

The frequency of anemia in the present study was much higher than that reported in India by Patel et al. [20] (25\%). This finding was expected, because most of the SCT subjects were referred to the center for evaluation and management due to different complaints including mainly pallor and infections.

The mean MCV obtained in this study was lower than the values reported for healthy individuals in Basra $(86.35 \pm 5.72 \mathrm{fL}$ for male and $87.09 \pm 5.94 \mathrm{fL}$ for female subjects $)$
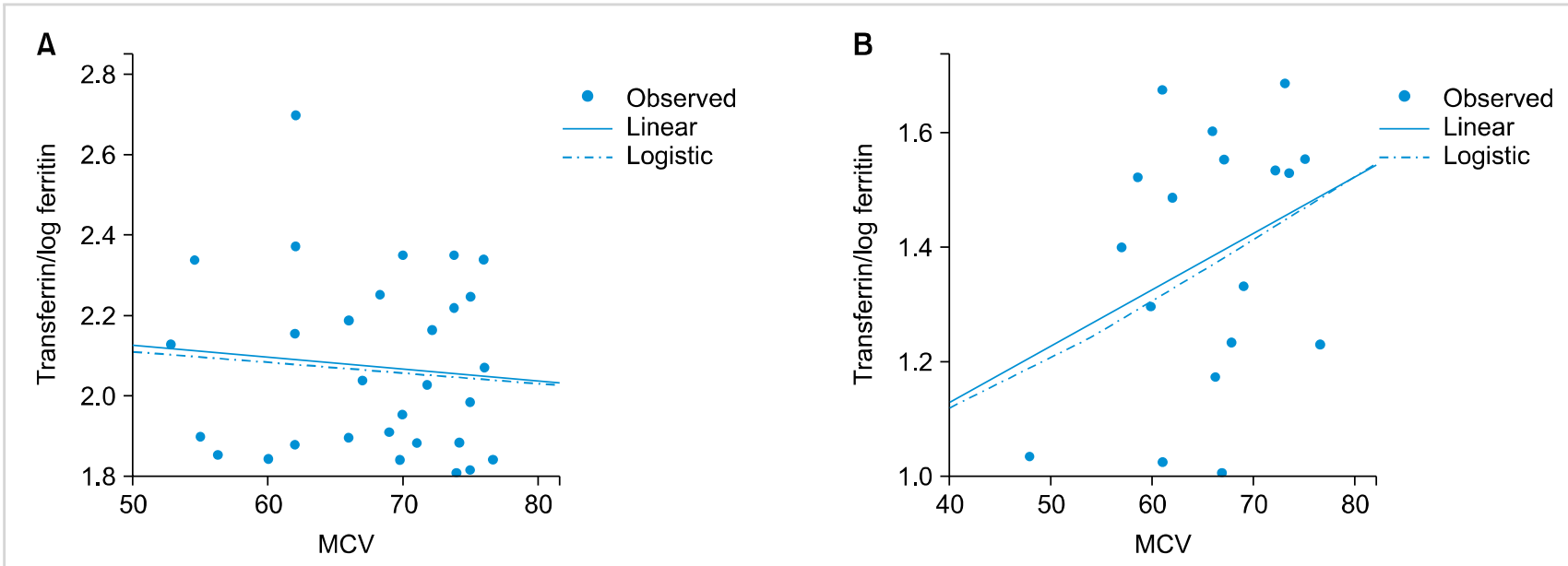

Fig. 2. Correlation between MCV level and iron status in ID SCT $(\mathrm{N}=63)(\mathrm{A}$, Spearman's rho, $-0.356 ; P=0.004)$, and non-ID SCT $(\mathrm{N}=18)(\mathrm{B}$, Spearman's rho, $0.258 ; P=0.301)$ children and adolescents with microcytosis. 
[17] and in international data $[14,15]$. This result is in agreement with the MCV reported by Patel et al. [20] (73.98 $\mathrm{fL}$ ) among children, adolescents and adults with SCT and Mohanty et al. [21] $(63.5 \pm 8.9 \mathrm{fL})$ in India. In contrast, the mean MCV was reported to be comparable to the values obtained in healthy individuals by Khan et al. [22] (89.4 48.7 $\mathrm{fL}$ ) in India, El Ariss et al. [23] in Lebanon (84.3 $\pm 7.6 \mathrm{fL})$.

In accordance with previous studies, MCVs were significantly lower in $\mathrm{HbAS}$ compared to $\mathrm{HbAA}$ participants. The effect of $\alpha^{+}$-thalassemia on the intra-erythrocytic concentration of $\mathrm{HbS}$ in $\mathrm{HbAS}$ subjects is well documented. Even in non-thalassemic HbAS subjects, the intra-erythrocytic concentration of $\mathrm{HbS}$ is lower than that of $\mathrm{HbA}$, probably because of the greater affinity of $\alpha-$ globin for normal $(\beta)$ compared to mutant $\left(\beta^{s}\right) \beta$-globin chains. However, the relative deficiency of $\alpha$-globin chains in subjects with co-existent $\alpha^{+}$-thalassemia appears to intensify this effect so that, compared to those with both HbAS and $\alpha^{+}$-thalassemia, the intra-erythrocytic concentration of $\mathrm{HbS}$ is roughly halved in individuals with $\mathrm{HbAS}$ and $-\alpha /-\alpha$ [11].

In this study, the mean MCV was significantly lower in males compared to that in females. In contrast, El Ariss et al. [23] reported a mean MCV in males of $84.7 \pm 7.4 \mathrm{fL}$, which was not significantly different from that in females $(84.1 \pm 7.8 \mathrm{fL})$. Moreover, the present study reported a low $\mathrm{MCH}$ among subjects with SCT, which was found to be significantly lower in males than females. The same finding was reported by Patel et al. [20], where the mean MCH was low (22.32 pg). These differences can be explained by the possibly higher prevalence of $\alpha$-thalassemia and IDA in Iraqi children and adolescents. In a national survey conducted in 2007, the prevalence of ID in Iraqi children aged 6 months to 14 years ranged from $50 \%$ to $70 \%$ [24]. The percentage of ID subjects with SCT was higher in this study than the national figures among the healthy population of the same age group.

The higher IDA among male subjects $\leq 5$ years of age (54.74\% of the studied SCT subjects) can be attributed to significant gender differences in $\mathrm{Hb}, \mathrm{MCV}$, ferritin, and transferrin receptors at infancy, suggesting a relative iron deficiency in boys. The gender differences in the abundance of $\mathrm{Hb}$ and transferrin receptors might reflect an increased risk for iron deficiency in boys, possibly because of gender differences in fetal iron accretion. However, for MCV, the remaining gender differences were independent of iron supplementation, growth variables, and complementary food intake, suggesting that other gender-related differences such as genetic or hormonal factors are responsible [25]. With regard to adolescents; significant differences between boys and girls in most eating habits and activity behaviors were reported, as boys were found to consume significantly more fast foods, sugar-sweetened drinks, and energy drinks than girls [26].

Although there are no data available concerning the prevalence of alpha thalassemia disorders in Iraq, the WHO reported that in Eastern Mediterranean regions, the frequency of these disorders constitutes $21.7 \%$ [27].
RBC distribution width-CV is significantly different between individuals with microcytosis and those with normal MCV. RDW-CV is known to be a sensitive and specific indicator of ID compared to other RBC indices [28]. In a study by Chikhlikar and Wilkinson [18] the mean RDW-CV was found to be $17.76 \pm 4.5 \%$ in symptomatic children and adolescents and $14.75 \pm 2.30 \%$ in asymptomatic subjects, while Patel et al. [20] reported a mean RDW-CV of $16.43 \%$.

To distinguish microcytic SCT subjects with and without ID, the ratio of transferrin to logarithm ferritin fully separated those with serum ferritin $<20 \mu \mathrm{g} / \mathrm{L}$ from the ones with ferritin $>100 \mu \mathrm{g} / \mathrm{L}$ with a cut-off at 1.70 . In the present study, most of the SCT subjects within the group of children younger than 5 years of age had microcytosis with ID, which is the age of increased metabolic demand [7, 24]. The high frequency of ID in SCT subjects in Basra is in contrast with the results of Al-Harbi et al. [29] in Saudi Arabia, who did not report ID in SCT patients with microcytosis.

Individuals with microcytic SCT and without ID had lower HbS proportions $(30.47 \pm 6.95 \%)$ compared to the $33.4 \pm 5.9 \%$ $\mathrm{HbS}$ proportion reported by Taha and Mansour [30] in Basra, which is also lower than the mean $\mathrm{HbS}$ in the present study sample $(31.15 \pm 5.30 \%)$. Another finding of this study was the absence of a significant association between MCV and iron status, which implies that microcytosis is not relevant to ID. This would suggest the co-inheritance of one form of alpha-thalassemia variants.

\section{Limitations of the study}

One limitation of this study is that it is hospital-based, with most of the SCT subjects being symptomatic, which would influence the percentage of those with microcytosis regardless of their iron status. Another limitation is the unavailability of a genetic study for those with microcytosis and no ID.

In conclusion, the majority of the studied SCT subjects had microcytosis. However, the distribution of iron status did not reveal significant changes in the frequencies of MCV among those with or without ID, indicating that microcytosis was not related to ID. We recommend further hematological and biochemical evaluations, which would be of significant importance to identify the causes of microcytosis.

\section{ACKNOWLEDGMENTS}

We would like to thank Dr. Jassim N. Al-Asadi, Professor of Community Medicine, for his assistance in conducting the statistical analysis of data and the laboratory staff of the Center for Hereditary Blood Diseases for their assistance and cooperation in completing the investigations.

\section{Authors' Disclosures of Potential Conflicts of Interest}

No potential conflicts of interest relevant to this article were reported. 


\section{REFERENCES}

1. Tsaras G, Owusu-Ansah A, Boateng FO, Amoateng-Adjepong Y. Complications associated with sickle cell trait: a brief narrative review. Am J Med 2009;122:508-12.

2. Naik RP, Haywood C Jr. Sickle cell trait diagnosis: clinical and social implications. Hematology Am Soc Hematol Educ Program 2015;2015:160-7.

3. Key NS, Derebail VK. Sickle-cell trait: novel clinical significance. Hematology Am Soc Hematol Educ Program 2010;2010:418-22.

4. Hassan MK, Taha JY, Al-Naama LM, Widad NM, Jasim SN. Frequency of haemoglobinopathies and glucose-6-phosphate dehydrogenase deficiency in Basra. East Mediterr Health J 2003;9:45-54.

5. Al-Allawi NA, Al-Dousky AA. Frequency of haemoglobinopathies at premarital health screening in Dohuk, Iraq: implications for a regional prevention programme. East Mediterr Health J 2010;16:381-5.

6. Iolascon A, De Falco L, Beaumont C. Molecular basis of inherited microcytic anemia due to defects in iron acquisition or heme synthesis. Haematologica 2009;94:395-408.

7. Miller JL. Iron deficiency anemia: a common and curable disease. Cold Spring Harb Perspect Med 2013;3:a011866.

8. World Health Organization. The global prevalence of anaemia in 2011. Geneva, Switzerland: World Health Organization, 2015:4-5.

9. Iraqi Ministry of Health. Nutrition Research Institute Iraq 2014. Baghdad, Iraq: Iraqi Ministry of Health, 2014. (Accessed February 15, 2016, at http://www.ffinetwork.org/about/calendar/2014/ documents/QIraq2014.pdf).

10. Medinger M, Saller E, Harteveld CL, et al. A rare case of coinheritance of Hemoglobin $\mathrm{H}$ disease and sickle cell trait combined with severe iron deficiency. Hematol Rep 2011;3:e30.

11. Wambua S, Mwacharo J, Uyoga S, Macharia A, Williams TN. Co-inheritance of alpha+-thalassaemia and sickle trait results in specific effects on haematological parameters. Br J Haematol 2006;133:206-9.

12. World Health Organization. WHO child growth standards. Geneva, Switzerland: World Health Organization, 2006. (Accessed March 22, 2016, at https://www.who.int/childgrowth/ publications/technical_report_pub/en/).

13. Cole TJ, Flegal KM, Nicholls D, Jackson AA. Body mass index cut offs to define thinness in children and adolescents: international survey. BMJ 2007;335:194.

14. Lewis SM. Reference ranges and normal values. In: Lewis SM, Bain BJ, Bates I, eds. Dacie and Lewis practical haematology. 10th ed. Philadelphia, PA: Churchill Livingstone, 2006:11-24.

15. Lo SF. Reference intervals for laboratory tests and procedures. In Kliegman RM, Stanton BF, St Geme JW, Schor N, eds. Nelson textbook of pediatrics. 20th ed. Philadelphia, PA: Elsevier, 2016:3464-73.

16. Castel R, Tax MG, Droogendijk J, et al. The transferrin/ $\log$ (ferritin) ratio: a new tool for the diagnosis of iron deficiency anemia. Clin Chem Lab Med 2012;50:1343-9.

17. Obaid AJ, Hassan MK, AL-Naama LM. Sickle cell and glucose-6-phosphate dehydrogenase deficiency gene in AbuAlkhasib district of southern Iraq. The Medical Journal of Basrah University 2001;19:12-8.

18. Chikhlikar K, Wilkinson A. A study of red cell parameters in patients of sickle cell trait. IOSR JDMS 2014;13:46-50.

19. Mustafa MH, Eltayeb EA, Elmisbah TE, Babiker HM, Ali NA, Nasir O. Frequency of the sickle cell disease and sickle cell trait in Heglig Area- Sudan. Int J Public Health Epidemiol 2013;3:1-6.

20. Patel J, Patel A, Patel J, Kaur A, Patel V. Prevalence of haemoglobinopathies in Gujarat, India: a cross-sectional study. Internet J Hematol 2008;5:1-6.

21. Mohanty D, Mukherjee MB, Colah RB, et al. Iron deficiency anaemia in sickle cell disorders in India. Indian J Med Res 2008;127:366-9.

22. Khan Y, Thakur AS, Mehta R, Kundu RK, Agnihotram G. Hematological profile of sickle cell disease: a hospital based study at cims, Bilaspur, Chhattisgarh. Int J Appl Biol Pharm 2010; 1:717-1.

23. El Ariss AB, Younes M, Matar J, Berjaoui Z. Prevalence of sickle cell trait in the Southern Suburb of Beirut, Lebanon. Mediterr J Hematol Infect Dis 2016;8:e2016015.

24. Tawfeeq U. Iraq National Micronutrient Survey 2007. Baghdad, Iraq: Iraqi Ministry of Health, 2007. (Accessed March 5, 2016, at https://studylib.net/doc/7795821/iraq-national-micronutrientsurvey-2007).

25. Domellöf M, Lönnerdal B, Dewey KG, Cohen RJ, Rivera LL, Hernell O. Sex differences in iron status during infancy. Pediatrics 2002;110:545-52.

26. Musaiger AO, Al-Mufty BA, Al-Hazzaa HM. Eating habits, inactivity, and sedentary behavior among adolescents in Iraq: sex differences in the hidden risks of noncommunicable diseases. Food Nutr Bull 2014;35:12-9.

27. Modell B, Darlison M. Global epidemiology of haemoglobin disorders and derived service indicators. Bull World Health Organ 2008;86:480-7.

28. Sultana GS, Haque SA, Sultana T, Ahmed AN. Value of red cell distribution width (RDW) and $\mathrm{RBC}$ indices in the detection of iron deficiency anemia. Mymensingh Med J 2013;22:370-6.

29. Al-Harbi T, Al-Matrafi M, Ismail A. Prevalence \& etiology of microcytosis in sickle cell anemia patients. IJIR 2016;2:622-6.

30. Taha JY, Mansour AA. Level of hemoglobin in sickle cell trait in Basrah using HPLC. MEJFM 2006;4:15-6. 